ІРИНА ЗЕЛЕНЕНЬКА, кандидат ббілологічних наук (м. Вінниия)

\title{
Лірика дисидентів Василя Стуса й Тараса Мельничука як опозиція тоталітаризму
}

Основа поетичного світу поетів-дисидентів Василя Стуса й Тараса Мельничука, в’язнів Зони 36, лавреатів Шевченківської прелії, - ие гострі межові переживання на грунті втрати індивідуальної свободи й державності. Роздули поетів навколо табірної безвиході, долі руху опору, перелолних, героӥчних молентів історї Украӥни знаходяться на межі модерністської та постлодерністської практик, почасти завдяки вдалил опозиціял образів-силволів життя $і$ слерті, батьківщини та чужини, честі й безчестя, тюрли та свободи, котрі збільшують алплітуду експресї, творів в’язнів концентраційних таборів СРСР, наближаючи ї̈ до глобальності політичного катастроббізлу ХХ століття й салі твори - до статусу докулентів доби.

Ключові слова: рух опору, дисидентська поезія, лодернізм, постлодернізл, екзистениія, спазлатичність.

Усвідомлення громадської приналежності до України як візійної держави, країни майбутнього - це ознака образного відображення реальності у ліриці поетів-дисидентів в'язнів тоталітарного монстра CPCP, учасників руху опору, Василя Стуса, Тараса Мельничука, Ігоря Калинця, Івана Світличного, Миколи Руденка, Ірини Стасів-Калинець, Станіслава Чернілевського, В'ячеслава Чорновола, Атени Пашко та ін. Антологія «Поезії із-за грат» (Київ, 2012) [7], яку вважають унікальним виданням дисидентської музи, де зібрано вірші переслідуваних мистців, дозволяе виводити поняття «поезія із-за грат» в окремий, не васальний, як вважалося раніше, термін, що може позначати не науково-популярні підходи до явища, а літературознавчі. У грунтовних розвідках Івана Дзюби [7], Володимира Моренця [5], Миколи Жулинського [2] розроблено активну терміносистему, що добре інтерпретуе дисидентську поезію. Проте варто відзначити гострий екзистенційний скептицизм, породжений не менш гострим розумінням перманентної блокади української національної культури в СРСР [3]. 
Дефіцит християнської моралі, європейський гуманізм, ідеї поза політичною ідейність - те, чого почали домагатися учасники опору в 60-х роках XX століття, під завісу відлиги; відліком прийнято вважати акцію протесту під час прем'єри художнього фільму Сергія Параджанова, екранізації «Тіней забутих предків» Михайла Коцюбинського в кінотеатрі «Україна» у Києві, у вересні 1965 року.

Творення образів у націософрському ключі було відповіддю нонконформістів [3] на згортання відлиги, варіантом езопової мови. Особливо яскраво це простежуеться у віршах Василя Стуса й Тараса Мельничука, в’язнів Зони 36. Їх об’єднує не лише трагічна доля переслідуваних та інакомислячих, а й окремі знакові моменти біографії: фрілологічного штибу освіта (Тарас Мельничук навчався в Літературному інституті імені Максима Горького, Василь Стус - на історико-фрілологічному факультеті педагогічного інституту в Сталіно), праця на шахтах (Тарас Мельничук замолоду працював на Донбасі); їх об'єднуе Поділля - Василь Стус народився на Вінниччині в селі Рахнівці, Тарас Мельничук пращював на Ямпільщині журналістом, другий термін ув'язнення (1979 - 1983 рр.) відбував у Вінницькій тюрмі (через інцидент, спровокований КДБ). Причиною першого арешту гуцульського поета під час масових репресій 24 січня 1972 року став рукопис поетичної збірки “Чага», зданої до видавництв «Карпати» i «Радянський письменник». Із 1972 по 1975 рp. Тарас Мельничук відбував покарання в Пермських таборах (Кучино, ВС-389/36-1, а тепер Чусовський район Пермського краю, Російська Федерація); а Василь Стус відбував у Кучино другий термін (арешт відбувся у 1980 р.) мистця засудили на 10 років примусових робіт і на 5 років заслання. Тараса Мельничука чекав і третій термін, але після аварії на ЧАЕС влада ніби забула про опального письменника, натомість згодом у рідному карпатському селі Уторопи було спалено хату письменника й неопубліковані рукописи [4, с.5].

Отже, Василь Стус і Тарас Мельничук відбули два політичні терміни, при цьому за другим терміном гуцульському поетові влада сфрабрикувала справу нетипову для дисидентів. Звернімо увагу також i на назви збірок віршів обох поетів, котрі промовисто свідчать про злам модерністської імпрези і рух у бік постмодернізму (парадоксальність, оксиморонічність, густа метафоричність, аж до субметафоризації та апокаліпсизм). Перший термін ув'язнення Тараса Мельничука знайшов відображення в збірці «Із-за грат» (1982 р., Торонто); другий найімовірніше у назві міфрічної книги «Строфи із Голгофии (Велика Британія, 1990 р.), нині точаться дискусії про достеменність фракту їі 
видання, табірна свідомість уповні відображена в збірці «Князь роси» (1990р.), за яку письменник отримав Шевченківську премію [4, с.5]. Перший Стусів термін у таборах провіщає «Веселий цвинтар» (1971р.), Мордовсько-Магаданський період ув'язнення i примусових робіт відображено у збірках «Час творчості» (1972 р.) і «Палімпсести» (1971 1977 рр., опублікована в 1986 р.), до 200 віршів було у рукописі збірки «Птах душі», вилученої агентами КДБ [1, с.5]. А тому зрозуміло, чому «Із-за грат» - певна уніфікаційна фрорма для сприйняття міфосвіту упослідженої терором людини-протестанта; це висловлювання, яке 3 уламку міфру всередині ліричного верлібристичного тексту Тараса Мельничука перейшло в назву його збірки й перетворилося на поняття щодо позначення табірної поезії дисидентів.

Табірна безвихідь - це тавро для світу, майже таке ж, як і самі табори, відображені в поезії Василя Стуса й Тараса Мельничука через мури, грати, міфрізовані й метафоризовані, за якими калина, сине поле, білий простір, мати: «За роком рік росте твоя тюрма, / за роком рік підмур'я в землю грузне, / і за твоїм жалінням заскорузлим, / за безголів'ям - просвітку нема» [8, с.78], «Добре мати два автомати / щоб хрест - навхрест вибити грати» [4, с.104].

На рівні політичних систем Василь Стус і Тарас Мельничук відчували себе в'язнями, абсолютна свобода й Вітчизна залишалися для них сенсом боротьби, а тому екзистенщійна поетична реальність, збагачена інтелектуальними та стихійними знаннями, драматичним досвідом та глибокими переживаннями, сформували широкий контекст усього, що поети намагалися висловити в період відновлення репресій.

Традиційна образна форма в опозиції до табірної дійсності - далека Україна разом із ї̈ ландшафтними реаліями, родинністю, саме у зв'язку з нею в ліриці дисидентів піднято чимало супутніх проблем тяглості й трансорормації історичної пам'яті в XX столітті, самопосвятності й жертовності борців за свободу, присутності батьківщини в підсоветському просторі, у соціумі зокрема, спротиву «совковості», прийняття й неприйняття фрізичної смерті, що е мізерною в порівнянні зі смертю духовною. Чи не найілюстративнішою, на наш погляд, тут є поезія Василя Стуса «Тюремних вечорів смертельні алкоголі...»: «Тюремних вечорів смертельні алкоголі, / тюремних досвітків сліпа, як близна, ртуть. / А сто мерців, обсівши серце, ждуть / моєї смерті, а своєї долі» [8, с.134]. Поет розкриває особливості побуту в'язнів: «I день при дні глевтяники жують, / аби чим-небудь душу закропити. / Валуе дим - то дні несамовиті / вершать а чи розпочинають путь - / по спогадах, що в пам'яті гніздяться, / по втратах, 
що тебе з усіх спромог / угору поривають, коли Бог / постав, як лютий бич і можновладця» [8, с.135].

Дисиденти - самозаглиблені вигнанщі, в’язні сумління, національні пророки: «І без волі можна, і без хліба. / I без чорної - на закуску - ікри. / I перехреститися мечем дуліба, / і податися за сіллю в Крим...» [4, с.205], тому ліричні герої їхніх віршів - особистості 3 розірваною свідомістю, заблоковано не лише політично, а й психологічно, із християнською та 3 дохристиянською свідомістю водночас: "Співають півні на святій Русі, / яка святою не була ніколи», «Моя земля святиня хліба і меча» [4, с.214].

Образи й символи тюремних віршів дисидентів - часто революційного штибу, із видозміненими закликами до боротьби, без сатисдакції на адресу свідомості пригноблених народів, супроти моральної нейтралізації; ї центрує міфічна вільна Україна в екзилі, патріархальна історична Україна, підсоветська українська територія. Звідси художнім двійником напівсюрреалістичної реальності як спроби врятуватися від тоталітаризму для дисидентів був націософрський екзистенційний простір: «Нема Вкраїни вдома» [8, с.79], «Нема Вітчизни» [8, с.90]. У медитативних спазмах Василя Стуса власне чуттевий рівень осягнення реальності поступився васальний по відношенню до інтелектуально-екзистенційного, що промовисто засвідчує поезія "Докучило! Нема мені вітчизни...» зі спадним градаційним запереченням: «Докучило! Нема мені вітчизни, / нема мені вітчизни - ні-ні-ні. / Душа горить в смертельному вогні, / разить мене - од запаху трутизни» [8, с.96], яке змінюють антитетичні пари 3 риторичним змішуванням та взаємозаміщенням макро й мікро: «Отак мені - чим далі од Вітчизни, / тим легшае, тим тяжчае мені. / Невже я сам-один на цілий світ, / вогненний скалок вікового гніву, / пізнав себе і долю цю зрадливу, / щоб проклинати чужинецький світ?» [8, с.97]. При цьому екзистенщійність підсилюеться сакральними й інфернальними формулами: «Нема мені коханої землі, / десь під грудьми пече гірка калина, / сміеться божевільна Україна / у смертнім леті на чужім крилі» [8, с.98].

Тарас Мельничук зі збірки до збірки вдавався до чуттевого екскурсу в історію державності України від найдавніших часів до апокаліпсичного, на його думку, XX століття, де алегоричний образ поета - доволі несподіваний, це риба з гачком у губі: «я риба / я в морі / у вільному морі / якщо не зважати / на маленьку дрібничку - / гачок у губі», «поети / бранщі й ланщі / i вовкулаки й сибіряки / i сніговіїхуртовини (я аж заплакав) / босі з України / у вікно дивляться / 
облизуючи місяць» [4, с.58]. Поезії опального гуцула властива сентименталізащія україніки, окремі зворушливі подробищі, що балансують на межі з інтимом: «плачу / хліб мій приріс / до чужого небокраю», «бодай прорости / маками гарячими / на твоїй, Україно, / терновій межі», «дзвонять по Вкраїні відра - / жінки небо беруть голубе», «тільки небо само / я подумав / це батьківщина / й пішов на дно». Відсутність Батьківщини - жорстоке покарання для поета, усі альтернативи чужини - тимчасові, навіть за наявності елементарних ознак рідного: «Я дивлюсь в твої очі, Сибір, / і радію, немов дитина, / вони в тебе такі голубі, / наче очі моєї Вкраїни» [4, с.240].

Образ України як опозиція тоталітаризму у віршах дисидентів двойлезий, прекрасний i парадоксальний, як життя в ХX столітті (неологізм узято з поезії «Бо що життя? Це усмішка двойлеза...» Ліни Костенко, яку теж зараховано до дисидентської платформи [1]); тобто це образ-дублет об'єктивно існуючої ландшафтної України i, разом із тим, візія бажаної незалежної України. Ліричний герой віршів в'язнів сумління із трансляцією України покрізь мури тюрми перманентно знаходиться то в діалозі, то в конфлікті з власною самістю, між двома явами батьківщини. Опозищійна до режиму Україна дисидентів - це своєрідний надобраз, що не стає васальним у жодній із книг письменників; тобто це не лише домінанта багатьох віршів, разом із тим, це образ-концепт, котрий прогресуе в метафорі та в символізації свободи: «О, земле втрачена, явися / Бодай у зболеному сні...» [8, с.134 ], «Із неволі йшла моя вітчизна / і собі везла візок із зорями» [4, с.190]. Тому зрозумілим є характерне вразливо-загострене, спазматичноекзистенційне відчуття-переживання й осмислення даності рідної землі, що має виразне фольклорне походження. У поезії Василя Стуса спостерігаємо кільце з легким, пісенним ритмом («О, земле втрачена, явися / Бодай у зболеному сні, I лазурово простелися, I душу порятуй мені.» [8, с.123]), а в поезії Тараса Мельничука - залежність від гуцульських паремій, містких афористично й риторично: «Благослови, мати, / за край свій стояти», «Ліпше своеї землі крупочок / ніж чужої горбочок», «О, земле! Дай крилатому коріння», «Щоб пізнати воду 3 джерела свого - / пити треба із джерел чужих», "На чужині не чужина, / якщо в душі - Вітчизна», “Хто народивсь для України - / той народивсь для боротьби», «Які тоді сміються, / як Вітчизна плаче?» [4, с.104-110].

Формами спротиву тоталітарній державі в поезії табірних періодів життя дисидентів стали топоніми, гідроніми, персоналії україніки, категоріальні ознаки етносу, історико-культурні та етнографічні фракти, окреме місце тут займає Тарас Шевченко: «Тарасові провісні птиці - 
Слова шугають над Дніпром» [8, с.68], «Я таке-то... дух Шевченка, / дух пісні живої, / а все інше, чумаченьки, / десь там, за горою» [4, с.109], при цьому гідронімічним центром українського простору для Василя Стуса залишався від збірки до збірки Дніпро, а в Тараса Мельничука частіше Дунай, Дністер, рідше - Дніпро. Для притчових творів гуцульського поета Тараса Мельничука властива каскадність і одивнення асоціацій; де постае трагічний символ приреченості мистця у країні терору: «Дивлюсь крізь грати на Карпати...» [4, с.48]. Стусова Україна часто приймае пейзажні образні форми, антропонімічні, властиві Шевченковій поезії, - це Україна-жінка, Україна-мати: «Осінь крилами в груди б'є. / О, Вкраїно моя осіння! / Чом забракло мені уміння / Звеселити серце твоє?» [8, с.168].

Відтак психологічні портрети дисидентського авторського «я» - це інтелектуал-відчаюга у Василя Стуса («Господи, гніву пречистого / благаю - не май за зле. / Де не стоятиму - вистою...» [8, с.95]), абсолютний бунтар у Тараса Мельничука («Тільки б чарка, чарка та вівчарка... « [4, с.302]), що йдуть на свідомий розрив із тоталітарною реальністю, апелюючи до периферійної свідомості мільйонів. Світогляд цих поетів побудований на зіштовхуванні життевих і мисленневих контрастів, на утворенні антитетичних пар навколо ситуативно протилежних реалій (табір і воля, поле і тюрма, храм і тюрма).

Постмодерне, а не власне модерністське, бачення підрежимної батьківщини визначаємо за наближеним до властивої апокаліпсизму розбудови порівнянь через фольклорне спростування. Знаходимо подібні форми в поезії Тараса Мельничука: «Наче тої Вкраїни / раз узяти на ложку» [ 4, с.65]. «беруся по тому / що куди не піду / не можу знайти свого дому» [4, с.69]. У віршах Василя Стуса це, знову ж таки, ще й включений у фольклоризаціею трагічний інтелектуальний парадокс: «О, краю мій! Наруго революцій, потворне посміховисько катів! I рай, і пекло - все тут під’яремне, тут навіть мертвих сором спопелив би, якби раніше кат не спопелив» [8, с.99].

Отже, чимало тюремних віршів дисидентів демонструють сучасному читачеві перехідне, від модернізму до постмодернізму, ретрансляційне й дифузне бачення батьківщини в колоніальному дискурсі й поза ним. Це спостереження вельми актуальне для подальших досліджень, оскільки український постмодернізм виник як природна реакція на деіндивідуалізацію тоталітаризму [6, с.433]. Апелюючи до опозиційних образних форм, Василь Стус і Тараса Мельничук залучили свого читача до пошуку свободи як гармонії, волі як субстанції життя, демократичної країни як гаранта соціокультурної 
ідентифрікації кожного.

\section{Список використаних джерел і літератури:}

1. Дисиденти. Антологія текстів. За ред. Олексія Сінченка. Київ: Дух і літера, 2018. 656c.

2. Жулинський М. Передмова / Мельничук Т. Князь роси: Вірші. Київ: Молодь, 1990. 152c. С.3-5.

3. Зелененька I. «Чиї це ілюзії стенають плечима, якого народу...»: Тарас Мельничук і літературний процес 60-90-х років в Україні. Вінниця: «Едельвейс i K», 2008. 152c.

4. Мельничук Т. Твори в трьох томах. / Пушик С. «Блакитна роса на траві й на колючому дроті...» : передмова. / Упорядники М. Андрусяк, М. Лазарук / Том 1-2: Поезії. Том 3: Есе, листи, спогади. Коломия: Вік., 2003.

5. Моренець В. Прощання з ідеологічною «вічністю». Українська поезія 80-90-х років /Золотий гомін: Українська поезія світу / Упорядник А.Мойсіенко. В 2 кн. Київ, 1997. Кн.2., 541с. С.455.

6. Лексикон загального та порівняльного літературознавства. Чернівці: Золоті литаври, 2001. 636c. С.433.

7. Поезія із-за грат. Антологія: Поетична творчість українських політв'язнів радянських тюрем і таборів. Київ: Смолоскип, 2012. 870 с.

8. Стус В. Палімпсест: Вибране. Передмова І. Дзюби. К.: Факт. 2003. 432c.

\section{References:}

1. Dysydenty. Antolohiia tekstiv. Za red. Oleksiia Sinchenka. Kyiv: Dukh i litera, 2018. 656s.

2. Zhulynskyi M. Peredmowa / Melnychuk T. Kniaz rosy: Virshi. Kyiv: Molod, 1990. 152s. S.3-5.

3. Zelenenka I. "Chyi tse iliuzii stenaiut plechyma, yakoho narodu...": Taras Melnychuk i literaturnyi protses $60-90$-kh rokiv v Ukraini. Vinnytsia: «Edelveis i $\mathrm{K} », 2008.152 \mathrm{~s}$.

4. Melnychuk T. Tvory v trokh tomakh. / Pushyk S. «Blakytna rosa na travi y na koliuchomu droti...» : peredmova. / Uporiadnyky M. Andrusiak, M. Lazaruk / Tom 1-: Poezii. Tom 3: Ese, lysty, spohady. Kolomyia: Vik., 2003.

5. Morenets V. Proshchannia z ideolohichnoiu «vichnistiu». Ukrainska poeziia 80-90-kh rokiv /Zolotyi homin: Ukrainska poeziia svitu / Uporiadnyk A.Moisiienko. V 2 kn. Kyiv, 1997. Kn.2., 541s. S.455.

6. Leksykon zahalnoho ta porivnialnoho literaturoznavstva. Chernivtsi: Zoloti lytavry, 2001. 636s. S.433.

7. Poeziia iz-za grat. Antolohiia: Poetychna tvorchist ukrainskykh politviazniv radianskykh tiurem i taboriv. Kyiv: Smoloskyp, 2012. $870 \mathrm{~s}$.

8. Stus V. Palimpsest: Vybrane. Peredmova I. Dziuby. K.: Fakt. 2003. 432s. 


\section{Summary \\ Iryna Zelenenka \\ The Lyrics of Dissidents Vasyl Stus and Taras Melnychuk as Opposition to Totalitarianism}

The basis of the poetic world of dissident poets Vasyl Stus and Taras Melnychuk, prisoners of Zone 36, Shevchenko Prize laureates are acute boundary experiences on the basis of loss of individual freedom and statehood. The reflections of poets around the camp reality, the fate of the resistance movement, the turning points, heroic moments of the history of Ukraine are on the verge of modernist and postmodern practices, partly due to the successful oppositions of life-and-death symbols, homeland and alien, prison and the crime of increasing the amplitude of expression, the works of prisoners of concentration camps of the USSR, bringing it closer to the globality of political catastrophe of the twentieth century and the works themselves - to the status of documents of the time.

Key words: resistance movement, dissident poetry, modernism, postmodernism, existence, spasmodics.

Дата надходження статті: «15» листопада 2019 р.

Дата прийняття до друку: «09» січня 2020 р.

\section{УДК 821.161.2 (Гай-Головко) \\ DOI: 10.31475/fil.dys.2020.10.07}

ЛЮДМИЛА КАПЛИЧНА, аспірантка

(л. Хлельницький)

\section{Жанрово-стильові особливості моделювання «вічної теми» в} ліро-епічних творах О. Гай-Головка

У статті вперше проаналізовано ліро-епічні твори О. ГайГоловка "Коханіяда", "Майдан св. Софбї» з точки зору жанровостильових особливостей моделювання "вічної тели". $У$ иьолу контексті осібно закиентовано на зображально-виражальних засобах, які усебічно розкривають талант поета. Засоби образності мови сприяли літератору втілити в словесну борлу конкретні уявлення про предлети і явища, увиразнити особисте ставлення до них. Доведено, що тропи в поемах виконують роль художнього обраллення, художньої довершеності, адже слова $i$ словосполучення, вжиті $y$ переноснолу значенні, корелюють естетичну ббункцію та художню реальність й у такий спосіб єлко розкривають світ і людину в ньолу.

Ключові слова: поема, "вічна тела", тропи, лодернізл, силволи, нарація, хронотоп. 